\title{
Commodification of Indigenous Knowledge: It's Impact on Ethno- medicine
}

\author{
${ }^{1}$ Minaketan Bag and ${ }^{2}$ Rashmi Pramanik
}

\begin{abstract}
I. Introduction
Indigenous Knowledge (IK) can be broadly defined as the knowledge that an indigenous (local) community accumulates over generations of living in a particular environment. This definition encompasses all forms of knowledge - technologies, know-how skills, practices and beliefs - that enable the community to achieve stable livelihoods in their environment._The indigenous communities have always generated, refined and passed the knowledge from generation to generation. Such "traditional knowledge" is an important part of their cultural identity. Traditional knowledge has played a vital role in the daily lives of the vast majority of people. Traditional knowledge is essential to the food security and health of millions of people in the developing country like India and state like Orissa. In many countries, traditional medicines provide the only affordable treatment available to indigenous community. In developing countries, up to $80 \%$ of the population depends on traditional medicines to help meet their healthcare needs (WHO Fact Sheet: 2002). In a simple sense, ethno medicine refers to the study of traditional medical practice which is concerned with the cultural interpretation of health, diseases and illness and also addresses the healthcare seeking process and healing practices. Now- adays the knowledge of the medicinal properties of plants has been the source of many modern medicines. During the last few decades, the demand of ethno medicine has increased significantly. The popularity of herbal drugs, herbal cosmetics and nutraceuticals has increased in India and in the world as well. The recent trend has simultaneously led to a heavy pressure on the ethno medicine and stealing of indigenous knowledge (WHO Fact Sheet: 2002).

The world has suffered and continues to suffer from a profound loss of indigenous peoples and rural groups and their knowledge about the natural world constructed from their intimate ties to land and place. This loss has been accompanied by neglect and the marginalization of their practices and beliefs, often figured as inferior forms of knowing to be replaced by universalized knowledge derived from the Western scientific tradition. While the latter tradition has great beauty, power and utility, attempts to apply it universally without regard for traditional knowledge systems has in many cases led to failures in sustainable resource use and the erosion of biological diversity. The imposition of scientific management regimes without the participation of local communities has prompted debate on whether the neglect of traditional knowledge violates human rights, civil rights, and indigenous rights. In recognition of these issues, there is a dramatically growing national and international interest in incorporating indigenous knowledge systems (IKS), including traditional ecological knowledge (TEK), into truly participatory approaches to development.
\end{abstract}

\section{Traditional Knowledge and Ethno medicine}

Traditional medicine refers to the procedure of protecting and restoring health that existed before the existence of modern medicine. The name traditional implies the approaches to health belong to the traditions of indigenous people, which have been handed down from generation to generation. This knowledge is used to sustain the community and its culture and to maintain the genetic resources necessary for the continued survival of the community. Traditional knowledge includes mental inventories of local biological resources, animal breeds, and local plant, crop and tree species. It may include such information as trees and plants that grow well together, and indicator plants, such as plants that show the soil salinity or that are known to flower at the beginning of the rains. It includes practices and technologies, such as seed treatment and storage methods and tools used for planting and harvesting. Traditional knowledge is also the belief systems of indigenous community that play a fundamental role in a people's livelihood, maintaining their health, and protecting and refilling the environment. Traditional knowledge is dynamic by nature and includes experimentation in the integration of new plant or tree species into existing farming systems or a traditional healer's tests of new plant medicines. The term "traditional" used in describing this knowledge does not imply that this knowledge is old or non-technical by nature, but is rather "tradition based". It is "traditional" because it is created in a manner that reflects the traditions of the communities, therefore not relating to the nature of the knowledge itself, but to the way in which that knowledge is created, preserved and disseminated (World Intellectual Property Organization: 2002). Thus, traditional knowledge is collective by nature and is often considered the property of the entire community, and not belonging to any single individual within the community. It is transmitted through specific 
cultural and traditional information exchange mechanisms, for example, maintained and transmitted orally through elders or specialists (breeders, healers, etc.), and often to only a select few people within a community. The knowledge of and uses of specific plants for medicinal purposes (often referred to as "traditional medicine") is an important component of traditional knowledge. In earlier days, traditional medicines were a major source of materials and information for the development of new drugs. In the $20^{\text {th }}$ century, however, new sources for pharmaceuticals led to a decline in the importance of ethno botany in drug discovery programs. However, new discoveries of potentially potent anti-cancer agents in plants (such as turmeric and taxol), as well as a rapidly growing herbal remedies market, has revived industry interest in traditional medicinal knowledge and practices. As interest towards traditional medicine is rekindled, indigenous knowledge of the cultivation and application of genetic resources is being exploited at an alarming rate. World sales of herbal medicine alone were estimated at US\$30 billion in the year 2000 (Grain and Kalpavrikash: 2002).

The spiritual dimension has a central role in this system of knowledge. It emerges from the intimate relationship with the natural environment and should not be confused with narrow understandings of "religion". In the context of indigenous world view, spirituality is understood as the recognition that everything in the universe is alive and requires respect. Further, there is an emphasis on an understanding of the interdependence of all beings in the world. Indigenous knowledge is characterized as cumulative, holistic, and practice-oriented; that is, it is not fragmented into categories or abstractions. Indigenous knowledge is expressed and transmitted through language (oral history, stories, songs, narratives, place names), social organization, everyday and ceremonial practices, observation, values, institutions, and laws. The intergenerational accumulation and communication of knowledge is central in indigenous systems of knowing. Indigenous knowledge is mainly acquired by long-term direct observation and experience (Daes: 1994).

\section{Bio-piracy}

Traditional knowledge has always been an easily accessible treasure and thus has been susceptible to misappropriation. The traditional knowledge, particularly, related to the treatment of various diseases has provided leads for development of biologically active molecules by the technology rich countries. In other words, traditional knowledge is being exploited for bio-prospecting. Also traditional knowledge is often misappropriated, because it is conveniently assumed that since it is in public domain, communities have given up all claims over it. There is no accepted definition of "bio-piracy." The Action Group on Erosion, Technology and Concentration (ETC Group) defines it as "the appropriation of the knowledge, genetic resources of farming and indigenous communities by individuals or institutions seeking exclusive monopoly control (usually patents or plant breeders' rights) over these resources and knowledge".

The adverse impact through the bio-piracy is a threat to the indigenous community and their knowledge system. Bio-piracy simply means 'our knowledge, their strength', i.e., based on clues available from our age-old traditions, the scientist of developed countries have succeeded in developing certain drugs from our natural products (like neem and haldi) and have claimed patent rights over the same without acknowledging our contribution to their research, and hence without acknowledging our share in intellectual property rights over the same.

\section{Neem:}

Neem is a legendary tree to India and has been used as a bio-pesticide and medicine in India for centuries. The shoot of the Neem tree are eaten. The oil also spermicide and can also be used as lamp fuel. Ancient Indian Ayurvedic texts have described the Neem tree and its medicinal healing practices are from $5000 B C$. Long before the toothpaste, Neem twigs was chewed for their anti-bacterial properties in India. Despite the traditional practices Neem, over 12 US patents were recently taken out Neem-based emulsions and solutions (Vandana: 1997). Four of the patents belong to U.S. Company W.R. Grace, which set up its own manufacturing plant in India for Neem-tree based pesticides (Vandana: 1997). Though Indian manufacturers were making Neem based bio-pesticides and toothpastes before W.R. Grace.s patents, W.R. Grace started claiming Indian companies for making Neem-based emulsions when it got its patent (http://www.american.edu/ted/neemtree.htm). In May 2000, the Opposition Division of the European Patent Office (EPO) revoked the patent which had been granted to the United States and W.R. Grace for the Neem tree fungicide, on the grounds that the claimed invention was lacking an inventive step, novelty, and that its properties were "prior art" years before the they applied for the patent (http://www.ifoam.org/press/win_final_neu.html). Vandana Shiva and others cited ancient Sanskrit texts to show that neem products had been used in India for centuries. The patents granted to WR Grace were blatantly false; the patent examiners had just not conducted an adequate prior art search and indigenous peoples were not sufficiently involved in the process (Vandana: 1997). 


\section{Turmeric:}

In 1993, the US PTO (Patent Trade Organization) granted the University of Mississippi Medical Center patent rights over Turmeric (Walker: 2001). But again, Turmeric has been used for centuries in India. The Indian Council for Scientific and Industrial Research (CSIR) alleged that the patent was void since it did not meet the novelty requirement and was obvious (Walker: 2001). The patent was eventually cancelled in 1998 after re-examination of the proceedings of patent grant (Gollin: 1999). It indicates how easy to patent the centuries old traditional knowledge.

\section{Basmati Rice:}

In 1997, the US patent office granted a patent in September 1997 to 'Rice Tec' for a strain of Basmati rice, an aromatic rice grown in India and Pakistan for centuries ago (Devraj: 2000). India claims that the granting of the patent violated the Geographical Indications Act under TRIPS, since Basmati rice is an indigenous to India and Pakistan. Indians argue that just as the US cannot label their wine as Champagne, they should not be able to label their rice Basmati. According the 'South Asia Commission on Economic and Social Policy, Rice Tec's patent also violated the CBD (Convention on Biological Diversity) in not recognizing the sovereign rights of India and Pakistan over Basmati rice (http://www.american.edu/TED/basmati.htm). The Basmati case demonstrates the problem as illustrated in TRIPS, which patents are granted to biotechnological processes. Thus, even though basmati rice has been in South Asia for centuries, Rice Tec just altered it slightly through crossing with a Western strain of grain, and successfully claimed it was its own.

India lost rights over several such products during the last two decades, and after much struggle (both at governmental and non-governmental level) has succeeded in getting patent rights over few such products revoked. Identification and separation of active principles responsible for the medicinal efficacy of any particular species is the first step which may (or may not) lead to bio-piracy. This phase is not of recent origin. For instance, isolation of strychnine from Strychnos nux-vomica was done as early as 1818 (Natural Products Radiance, January-February 2005, p.7). As the western scientists had the capacity as well as political (government) support to carry out such research activities, hence the credit for most of these kind of discoveries went to them till India (and other underdeveloped countries) could develop their own capacity in this regard. The irony is that the Government of India has always been lagging behind in ensuring an effective mechanism to check bio-piracy (Rath: 2005).

\section{Commodfication of Ethno medicine}

Medicinal plants assumed commercial significance since millennia, but it is only during the last few decades that its significance has increased remarkably with the growing production as well as popularity of herbal drugs, herbal cosmetics and nutraceuticals. The recent trend has simultaneously led to a heavy pressure on the medicinal plant resources of the country due to increased unsustainable exploitation of the same. In this context an assessment of the impact of globalization on such plants/resources has been very pertinent as there is an apprehension that globalization would lead to the overexploitation of country's resources (including medicinal plants). Export of our valuable resources to foreign countries, particularly the western countries, is supposed to be a major means through which globalization or the global trend can affect our country. On the other hand, there are other means also for exercising control over our resources by the western corporate sector. It may so happen that some of our own resources lose importance in the market by some propaganda against their efficacy. Similarly, it may also happen that we ignore our resources and give priority to those from outside but promoted by market forces. Hence, the adverse impact may either cause over-exploitation or underexploitation (Rath: 2005).

\section{Indian Context}

Indigenous Knowledge refers to the local knowledge of indigenous people that is unique to their culture or society. They utilize the knowledge in the field such as agriculture, education, health, natural resources management etc. These skills and knowledge are their internal creativity and experimentation of their livelihoods over a long period of time (World Bank: 2000). A major distinguishing characteristic of indigenous knowledge is that it is handed down from one generation to the next. Those who hold the knowledge preserved it as it were in trust for future generations. Indigenous knowledge has gained prominence of late as people realize the role it has played over time in preservation of biodiversity. The traditional knowledge may be described as any knowledge, innovation, or individual or collective practice of an indigenous people or local community, having real or potential value, associated with a biological resource, protected or not by intellectual property legislation. Indigenous medicine is the sum total of all the knowledge and practices, whether explicable or not used in diagnosis, preservation and elimination of physical mental of social imbalance and relying exclusively on practical experiences and observation handed down from generation to generation whether verbally or writing. It also considered as a social amalgamation of dynamic medical knowledge knows how an 
ancestral experiences (http://apps.who.int/medicinedocs/ documents/s7147e/s7147e.pdf) In India, traditional systems of medicine have been traced out. From over 7500 species of medicinal plants Ayurveda uses about 1769 species, whereas the use of approximately 289 medicinal plant species were documented in vedic literature. But by $1500 \mathrm{BC}$ to $500 \mathrm{AD}$ this number rose to approximately 650 and by $1900 \mathrm{AD}$ to 1814 (The Hindu: October, 2000). The volume and value of medicinal plants exported from India were 32882.8 tons and Rs.2159.518 million in 1996-97, which rose to 37976.3 tons and Rs.2377.952 million in 1998- 99, but reduced to 36617 tons and Rs.1764.799 million in 1999-2000 (Rawat: 2004). The export was further valued at US\$ 133.28 million (as against US\$ 112.46 million in 2000-01) in 2001-02. The conventional growth rate has been assumed at 15\% (EXIM Bank of India 2003:11-58). Despite this, India is yet to be in a position to compete with countries like China. It was estimated that when China's transaction was Rs.2500 crores and that of Thailand was Rs. 1000 crores, India could achieve a figure of Rs.436 crores only (Source: presentation at the seminar on medical and aromatic plants held at Orissa University of Agriculture \& Technology during 11 to 12 January' 2005). Malpractices by exporters and lack of value addition, etc. may be responsible for this lower rate of achievement in the export sector of medicinal plants. The domestic market in India consumes the major part of the production and that the threat to the availability of some wild species is reduced till their export increases substantially.

Speaking species-wise, the trend has witnessed some major changes during past 30 years. For instance, during 1974-75, crude opium topped the list of exported items followed by psyllium husk, kuth, zeodvary roots and senna leaves/pods(Botanical Survey of India 2000, Flora of India, Introductory volume, part II, p.350); but during 2001-02 psyllium husk(50.55 million US\$) topped the list followed by opium(16.82 million US\$), cambodge extract, other extracts, and henna powder(EXIM Bank of India 2003:67) in terms of the value of export.

However, speaking quantity-wise, psyllium husk (25581.75 ton) topped the list followed by senna leaves/pods(8237.85 ton), not-elsewhere-specified Ayurvedic and Unani drugs(7451.64 ton),henna powder(6732.89 ton) during 2001-02 (EXIM Bank of India 2003:.67). Export of value-added and finished products started decades ago, but their volume was negligible. For instance, VICCO Laboratories has been marketing its herbal tooth paste Vajradanti, in the US for more than 25 years. Similarly, the Himalaya Drug Company is known in the US since many years for its product Liv-52 (Dharmananda S. 2003, The Ayurvedic Medicine Industry in India, online paper). However, as said earlier, the volume of such export was negligible; and although the situation has improved during the last decade, still about $73 \%$ of our exports (medicinal plants) were in the form of crude drugs and extracts, the rest being in the finished form. It is expected that with more and more emphasis on exporting finished products, the situation will improve further (EXIM Bank of India: 2003)

\section{Odishan Situation}

For millennia, human in every corner of the world have accumulated knowledge about plants. This knowledge has been gathered and transmitted orally and textually through generations. Some of the knowledge is the product of modern science; a precise method for learning about plants. Ethno botanical research is providing fundamental information in the search for new drugs, foods, pesticides, natural products, gene resources and chemicals. The tribal, in general are endogamous groups sharing common language and culture. They are living under varying geo-ecological setting of hills and forest areas and far away from modern convenience of life. They are the economically backward ethnic group. They are food gatherers, hunters, forestland cultivators, and minor forest produce collectors. They live in isolation near to nature. Orissa with its 7 million tribal populations of 62 different ethnic groups inhabiting in the dense and thick tropical forest areas possesses rich empiric knowledge about plant wealth.

There are 2727 plant species identified in Orissa, out of that approximately $1200(44 \%)$ are in use for medicinal purposes (The Samaj, 11-2-02). But the Government of Orissa has recorded the availability of 135 medicinal plant (wild) species in the state (The Sambad, 11-3-02). Out of about 620 medicinal plants in trade in India, about 100(16.12\%) are found in Orissa (The Samaj, 11-2-02). From a total number of the top 20 medicinal plant species in trade in the country nearly 10 are found in Orissa. Almost all the medicinal plant resources of Orissa are collected from the wild, either from forests, or from waste lands. Few like koilekha are collected from other areas like paddy fields, fences, etc. Attempt has been very recently made to cultivate some species on commercial basis, but the contribution from cultivation is negligible (The Samaj, 11-2-02).

An estimate of annual transaction of medicinal and aromatic plants in Orissa was Rs.10 corers (source: presentation at the seminar on medicinal and aromatic plants held at Orissa University of Agriculture and Technology) during January 11 and 12, 2005). This suggests that the transaction in Orissa is within $2 \%$ to $3 \%$ of the national transaction valued at approximately Rs.440 corers. However, being an extremely unorganized market, a considerable part of the actual transactions might have gone under reported (Srivastava: 2005). Out of a total number of 1076 plant species identified in Shimilipal, about 552(51.30\%) are considered to be medicinal 
whereas only 70 of them are used extensively. However, over exploitation has caused scarcity of species like gajapippali, gudmari, sweta-kaincha, chitaparu(red), bhuichampa, ramdantun, and mruta-sanjeevani etc.(Subuddhi: 2002).

In the year 2000, a newspaper report reveals about several medicinal/herbal NTFPs (Non-Timber Forest Products) being supplied from interstate boarder areas of Orissa, MP (Chhattisgarh) and Bihar (Jharkhand) particularly for export purposes. It said that some American companies had been facilitating such kind of collection and supply and that this had increased the apprehension of losing patent rights over many of our own resources as compared to the western companies/scientists. This report paid specific attention to the resources of Gandhamardan, suggesting that the trend in the border areas had posed a threat to the bio-diversity of Gandhamardan. It enlists the following species supposed to be more vulnerable under such circumstances: Harida, sahada, gudmari, arakh, nagodari, chiraita(bhuineem), hadapodi, bada kaniara, dudura, akarkara, sarpagandha, satyanashi, mruta-sanjeevani, and ghrutakumari, etc.(The Samaj, Sambalpur edition, 12-6-2000). The report said that there had been a boost to the supply of several NTFPs (Non-Timber Forest Products) of medicinal and other importance during the last 5-6 years. It also mentioned how the poor primary collectors of these items had remained ignorant about the conspiracy behind this kind of collection for which they are but marginally paid.

Gandhamardan hills, Sunabeda plateau, and forests of Thuamul-Rampur are some of the hotspots where medicinal plant resources are abundant in western Orissa. Gandhamardan hills of western Orissa are famous for its rich medicinal plant resources since centuries. Out of the total 450 species of plants found there, about $250(55.55 \%)$ have been identified as medicinal plants (The Samaj, 11-2-02). Rayagada is a major centre for the trade of RS roots. A leading NTFPs trader (name withheld) of the region says that although the current potential of the district is limited to 5 to 6 tons(dry) only, actual trading takes place for 10 to 20 tons(raw or semi-dried) and this extra quantity is ensured from the neighboring districts like Koraput. It speaks about 15 to 20 years ago, how the supply from this region amounted to 10 to 12 tons(dry) which has now reduced to 3-4 tons only(weigh loss is more or less $65 \%$ ). 18 were treated of upper respiratory tract infections and digestive disorders, etc. This plant is also available in the wild jungle but forest collection is almost absent probably because the cost of production is not affordable. Rayagada district is said to have the potentiality of producing about 5 to 6 tons of banajeera (dry) per annum. The actual trade is being limited to 3-4 tons only. For baibidang, the potentiality is about 50 tons (dry). The actual trade takes place for 50 to 100 tons. The potentiality of amla (raw) is about 100 tons and almost an equal quantity is traded (Rath: 2005).

Even though the tribal use most of the wild plants in different ways in their day-to-day life still then the food habits and healing systems are fast changing due to non- availability of genetic resources. The rich and untapped flora, which tribal societies have been using for food, medicine, etc need to be investigated with a view to develop new sources of proteins, fats, starches, alkaloids, therapeutic agents etc. The tribal of different districts represent an invaluable, indigenous knowledge base. Some of which are documented but by large to be explored. The ethno medical knowledge of these tribal may provide a strategy for discovery of clinically useful compounds from plant sources.

\section{Impact of Globalization on the Medicinal Plant Resources}

The value system of our country has been severely affected by the current trend of market-driven life style. Chyavanprash, a sacred medicine, has now become a play ball in the hand of market forces who have not only used it for their financial benefit but have also made several modifications in the original formulation in their commercial interest ultimately making it a dietary supplement. Natural shampoo-producing items like shikakai and ritha have disappeared from the use pattern at local level, and have instead entered in their costlier and value-added forms in herbal shampoos. The name and fame of chemical viagra was used to promote safed musli. The current trend is gradually making people more and more dependent on the corporate sector and direct use of basic ingredients and/or domestic level processing have been losing its ground.

Report speaks that after the patenting of neem by a western company, some people in India thought that their neem trees would no longer belong to them. This rumor resulted in the cutting of several neem trees in some parts of West Bengal. On the other hand, over-exploitation both for domestic and export market has made species like Taxus baccata, and Swertia chirayita critically endangered in the north-east (Source: Mukesh Jain). Estimation shows that 120 economically useful plants in India are endangered and 35 of which are medicinal plants (Dharmananda: 2003).

However, Darshan Shankar, the Executive Director of Bangalore-based FRLHT (Foundation for Revitalization of Local Heath Traditions) a leading non-government organization working in the medicinal plants sector across the country does not see any noticeable impact of globalization on Indian medicinal plants particularly because our share in the export market is very marginal. Even the Himalayan Drug Company, the largest exporter of finished herbal products, could achieve an export turnover of only Rs. 50-60 corers as compared to its total turnover of about Rs. 300 corers. Wild collection of medicinal plants has been estimated to 
generate about 40 million maydays of employment in the country, per annum (The Times of India: 2000). But the share of the primary collectors in the total turnover of herbal market is about $0.0001 \%$ (presentation at International Conference on Medicinal Herb and Herbal Products). In such a situation the poor section has been affected by the trend in the market and has started depending on the corporate sector for various products like shampoos and medicines, etc. Hence they are likely to suffer the financial implications of this dependency. Further change in utilization pattern has increased the risk of indigenous knowledge base.

Overexploitation has always been facilitated by an increase in demand and/or price. This has been seen in case of various species but the trend has been often species-specific. For instance, in 1966-67, the quantity of belladonna collected from wild was 81 quintals which was reduced to only 4 quintals in the year 1974-75. Similarly, exploitation/ utilization of Vinca rosea for export is not a recent phenomenon, but it has started since mid-1960s (Botanical Survey of India: 2003: 351-352). The export of Ayurvedic and Unani herbs in 1974-75 amounted to 117.8 tons (Botanical Survey of India: 2003:352) which increased to 1146.7 tons in 2003-04. This may at first suggest a tremendous increase in the pressure on the resources. The ground reality may or may not be true depending on the species. For instance, in 1987-88, myrobalans other than amla, i.e., harida, etc. were exported(for tanning purpose) to the tune of 278.17 tons which increased to 370.852 tons in 2002-03. The fact being that a lot of the harida and bahada produced in the country still go waste due to want of takers. Hence, in this particular case increase in export would indicate increase in the scope of optimum utilization of the resource. On the other hand, the opposite has happened in case of amla. In 1987-88, the quantity exported for tanning purpose was 304.659 tons which was reduced to 107.201 ton in 1992-93; but in 2002-03 the quantity was 254.417 ton (based on DGCIS data). The substantial reduction in 1992-93 does not actually mean that the wild plants of amla were benefited from this because heavy internal demand and other factors caused large scale cutting of amla trees for convenience in collection of the fruit (Rath: 2005).

\section{Importance of Protecting Intellectual Property Rights}

Intellectual property laws were devised to protect products of human intellect that have some economic value. The primary purpose of intellectual property (IP) as gleaned by the framers of the constitution is "to promote the progress of science and the useful arts." The forms of IP include copyrights, trademarks, patents and trade secrets. Patents protect the functional features of a machine, process and manufactured item, method of doing business, composition of matter, ornamental design or an asexually reproduced plant. It also protects new uses or improvements on such items. Once a patent is granted, an inventor is given a monopoly on the use and commercial exploitation of the invention over a limited time.

The development of new technology and the new use of traditional knowledge based products today is the major threat to the survival of many of these communities. The modern cultural industries as well as the manufacturing industries these days, commercially exploit the traditional knowledge based products using new technology without the permission and sharing of profits with the communities. Now-a-days it is possible to bring out new products or find out new use of existing products based on traditional knowledge utilizing the technological developments in the field of biotechnology. This is beyond imagination particularly in the field of medicines, agriculture etc. The development of new products or new uses of existing products enable the industries to get protection for these products through the formal intellectual property laws (Jain: 2008).

Intellectual property rights should guarantee both an individual's and a group's right to protect and benefit from its own cultural discoveries, creations, and products. But the current IPR system cannot protect traditional knowledge for three reasons. First, the current system seeks to privatize ownership and is designed to be held by individuals or corporations, whereas traditional knowledge has collective ownership. Second, this protection is time-bound, whereas traditional knowledge is held in perpetuity from generation to generation. Third, it adopts a restricted interpretation of invention which should satisfy the criteria of novelty and be capable of industrial application, whereas traditional innovation is incremental, informal and occurs over time. An alternative law is therefore necessary to protect traditional knowledge.

Western intellectual property regimes focusses on protecting and promoting the economic exploitation of inventions with the rationale that this promotes innovation and research. Western intellectual property law, which is rapidly assuming global acceptance, often unintentionally facilitates and reinforces a process of economic exploitation and cultural erosion. It is based on notions of individual property ownership, a concept that is often alien and can be detrimental to many local and indigenous communities. An important purpose of recognizing private proprietary rights is to enable individuals to benefit from the products of their intellect by rewarding creativity and encouraging further innovation and invention. But in many indigenous world-views any such property rights if recognized at all should be extended to the entire community. They are a means of maintaining and developing group identity as well as group survival, rather than promoting or encouraging individual economic gain (Hansen and VanFleet: 2003). 


\section{Ethical Dilemmas of not Protecting IK}

Given the problems of protecting indigenous knowledge there are, however, some ethical dilemmas of not protecting it. Ng'etich (2005) points these out clearly:

- Many communities that own documentation are slowly disappearing and their way of life is changing. It is therefore crucial that IK be preserved through documentation.

- Although there are issues with Western technology through multinational corporations bankrolling the appropriation of IK, it is a fact that this technology is required, as many communities do not have the means to facilitate the appropriation.

- Not documenting IK means that it is taken to be in the public domain, to be picked up and used by anyone who has the means. Documenting it means that there is a database against which patent claims can be checked.

- Knowledge and information have been shown to be the means to development and economic benefits, protecting and securing IK for appropriation by the communities themselves, through what Ruiz (2005) refers to as contracts and know-how licenses that regulate access to IK and establish terms under which such IK can be used, as well as the way in which communities should benefit.

A patent gives a monopoly right to exploit an invention for 17-20 years. To be patentable an invention must be novel, inventive and have a commercial use. Controversially though, the US and European patent office's now grants patents on plant varieties, GM crops, genes and gene sequences from plants and crops. The current WTO patent agreement, TRIPs - Trade-Related Aspects of Intellectual Property Rights - has been very controversial in this respect for many developing countries who want to have it reviewed, but are being somewhat blocked by the wealthier nations from doing so.

\section{Conclusion}

There has been an increasing recognition of the value of indigenous knowledge. But it has also become a serious concern of appropriation and commodification of this knowledge particularly by the pharmaceutical industry. Terms like "bio piracy" and "bio prospecting" refer to appropriating and patenting aspects of indigenous knowledge to be used in pharmaceutical and medical products without sharing the profits with the holders of this knowledge. Globalization and the knowledge economy have exposed the potential and actual value indigenous knowledge has yielded to the world's most powerful multinational corporations. At the same time too, globalization has negated indigenous knowledge by viewing it as untried and untested unless processed by Western technology. Indigenous knowledge has also been individualized and commercialized to the point where symbols that are held sacred by communities are trivialized as slogans and logos, which are used and patented. The protection of indigenous knowledge has become a major concern and an issue of much debate internationally at organizations such as the United Nations, United Nations Educational, Scientific and Cultural Organization (UNESCO), and the World Intellectual Property Organization. Therefore, developing nations also should promote awareness of indigenous peoples' rights stemming from their valuable knowledge, and the trustee should invoke trade secret protection whenever possible to prevent the misappropriation and misuse of indigenous peoples' knowledge. This approach would have several advantages including helping prevent unjust enrichment and cultural theft. Furthermore, indigenous people would be empowered and would have a means to obtain monetary compensation if outsiders misused their knowledge or resources. Indigenous people also would have a means to protect their resources and control the use of their resources.

\section{References}

[1] Botanical Survey of India. 2003. Flora of India, Introductory volume, Part II, 350.

[2] Daes Erica-Irene A. 1994. "Preliminary report of the Special Rapporteur on the protection of the heritage of indigenous people", Geneva: UN Sub-Commission on Prevention of Discrimination and Protection of Minorities.

[3] Devraj R. 2000. US Corporate Biopirates Still Staking Claim on Basmati Rice, Common Dreams New Center, Available at http://www.commondreams.org/headlines/ 100900-01.htm.

[4] Dharmananda S. 2003. The Ayurvedic Medicine Industry in India, online paper. Available at: http://www.itmonline.org/arts/ayurind.htm.

[5] EXIM Bank of India. 2003. Export Potential of Indian Medicinal Plants and Products, pp.11-12.

[6] Gollin M. 1999. New Rules for Natural Products,. Sept. Vol. (17)9:.921.922, Available at: http://www.nature.com/cgitaf/DynaPage.taf?file=/nbt/journal/v17/n9/full/nbt 0999_921.htm

[7] Grain and Kalpavriksh. 2002. "Traditional Knowledge of Biodiversity in Asia Pacific: Problems of Piracy and Protection", Genetic Resources Action International, October, Available at: http://www.grain.org/publications/tk-asia-2002-en.cfm.

[8] Hansen S and VanFleet J. 2003. "Traditional Knowledge and Intellectual Property: A Handbook on Issues and Options for Traditional Knowledge Holders in Protecting their Intellectual Property and Maintaining Biological Diversity", Association for the Advancement of Science, American: Washington, DC Available at: http://shr.aaas.org/tek/handbook.

[9] Jain V. 2008. "Safeguarding the Traditional Knowledge in India" Paper Presented in the Seminar of Asia Pacific Jurist Association (APJA): Delhi, on 28.04.2008.

[10] Ng'etich K A. 2005. Indigenous Knowledge Alternative Medicine and Intellectual Property Right Concern in Kenya. Paper Presented at the Council for the Development of Social Science Research in Africa (CODESRIA) General Assembly, Maputo, Mozambique, 6-10 December, 2005 
[11] OUAT. 2005. Seminar Presentation on Medicine and Aromatic Plants at Orissa University of Agriculture and Technology, Bhubaneswar during January11-12.

[12] Rath Bikash. 2005. Globalization, Global Trend in Herbal Market, and The Impact thereof on Medicinal Plants in Orissa, Available at: www.vasundharaorissa.org.

[13] Rawat A K S. 2004. Adulteration \& Substitution of Herbal Drugs in Indian Market, presentation at ICMHHP.

[14] Ruiz M. 2004. Policy Brief: National and Regional Law to Protect Indigenous Knowledge Related to Genetic Resources. SciDev, Net. Available at: http://www. scidev.net/en/health/traditionalmedicine/policy-briefs/national-and-regional-laws-toprotectikrelated.html.

[15] Srivastav S. 2005. Shalapuja, March. Conservator of Forest Berhampur Circle.

[16] Subuddhi D. 2002. Shimilipalara Oushadhiya Brukshyalata, The Samaj, $11^{\text {th }}$ December, 2002.

[17] The Dharitri, $30^{\text {th }}$ December, 2002.

[18] The Hindu Health Folio, $7^{\text {th }}$ October, 2000; pp.7, 14-15.

[19] The Samaj, $11^{\text {th }}$ February, 2002.

[20] The Samaj, Sambalpur edition, 12-6-2000

[21] The Sambad, $11^{\text {th }}$ March, 2002.

[22] The Times of India: 2000, Bhubaneswar

[23] Vandana S. 1997. Biopiracy: The Plundered of Nature and Indigenous Knowledge, Boston: South End Press.

[24] Waker S. 2001. "The Trips Agreements: Sustainable Development and the Public Interest" Centre for International Law; IUCN Environmental Law Center.

[25] WHO. 2002. Fact Sheet. June No. 271. Available at: http://www.who.int/medicines/ organization/trm/fact sheet 271 .doc

[26] World Bank. 2000. What is Indigenous Knowledge System. World Bank Web Site.

[27] World Intellectual Property Organization. 2002. Elements of A Sui Generis System For The Protection Of Traditional Knowledge, World Intellectual Property Organization, Intergovernmental Committee On Intellectual Property And Genetic Resources, Traditional Knowledge And Folklore, 3rd Session. WIPO/GRTKF/IC/3/8. 